\title{
PENYULUHAN PEMANFAATAN LIMBAH PLASTIK SEBAGAI BAHAN BAKAR ALTERNATIF DI SMK TELKOM PEKANBARU
}

\author{
Jusnita*, Denur, Indra Hasan, Yuhelson, M. Ridha Fauzi, Japri \\ Program Studi Mesin Otomotif, Fakultas Teknik \\ Universitas Muhammadiyah Riau \\ email: jusnita@umri.ac.id
}

\begin{abstract}
He purpose of this community service is to provide information about the use of plastic waste as alternative fuel for vocational students and Telkom Pekanbaru teachers and to help graduates of vocational students in facing the world of work. The method used is lecture, question and answer, discussion, demonstration. The benefits of this service are; a) Provide scientific contributions, namely theoretical contributions in the form of additional scientific repertoire in the field of engineering studies, especially in the field of studies on the utilization of plastic waste for students of Pekanbaru Telkom Vocational School b) Lecturers can carry out one of the three principles of Higher Education, c) Help the community in unemployment. The results of community service activities broadly include the following components; 1). The success of the target number of participants is more than the planned target. 2) Planning an environmentally friendly movement towards the prosperity and utilization of plastic waste as an alternative fuel in the Final Waste Management Site (TPSA) in Pekanbaru Telkom Vocational High School, 3) The achievement of material targets in this service activity is quite good, because extension materials can be delivered overall 4). Targeted counseling participants as planned before 20 people who majored in TKR and TSM. In its implementation, this activity was attended by 40 participants. Thus it can be said that the target of the participants is reached 100\%. This service level has been published in print media (tribune).
\end{abstract}

Keywords: Plastic Waste, Alternative fuel

\begin{abstract}
Abstrak
Tujuan pengabdian masyarakat ini adalah untuk memberikan penyuluhan tentang pemanfaatan limbah sampah plastik sebagai bahan bakar alternative untuk siswa SMK dan guru Telkom Pekanbaru dan membantu lulusan siswa SMK dalam menghadapi dunia kerja. Metode yang digunakan adalah ceramah, Tanya jawab, diskusi, dan demonstrasi. Manfaat pengabdian ini adalah; a) Memberikan kontribusi ilmiah yaitu sumbangan teoritis berupa tambahan khasanah keilmuan dalam bidang studi ilmu keteknikan, khususnya dibidang kajian mengenai pemanfaatan limbah sampah plastik untuk siswa SMK Telkom Pekanbaru b) Dosen dapat melaksanakan salah satu tri darma Perguruan Tinggi, c) Membantu masyarakat dalam pengangguran. Hasil kegiatan pengabdian masyarakat secara garis besar mencakup beberapa komponen sebagai berikut; 1). Keberhasilan target jumlah peserta lebih dari target yang direncanakan. 2) Merencanakan gerakan ramah lingkungan menuju kemakmuran dan pemanfaatan limbah sampah plastik sebagai bahan bakar minyak alternatif di Tempat Pengolahan Sampah Akhir (TPSA) di SMK Telkom Pekanbaru, 3) Ketercapaian target materi pada kegiatan pengabdian ini cukup baik, karena materi penyuluhan telah dapat disampaikan secara keseluruhan 4). Target peserta penyuluhan seperti direncanakan sebelumnya 20 orang yang jurusan TKR dan TSM. Dalam pelaksanaannya, kegiatan ini diikuti oleh 40 orang peserta. Dengan demikian dapat dikatakan bahwa target peserta tercapai $100 \%$.
\end{abstract}

Kata kunci : Limbah Plastik, Bahan bakar alternatif 


\section{PENDAHULUAN}

Sumber Daya Manusia (SDM) yang berkualitas ialah tenaga kerja siap pakai, yakni tenaga kerja yang menunjukkan penguasaan ilmu pengetahuan, teknologi, dan keterampilan yang tinggi diikuti dengan moral, etika, dan karakter diri yang baik.

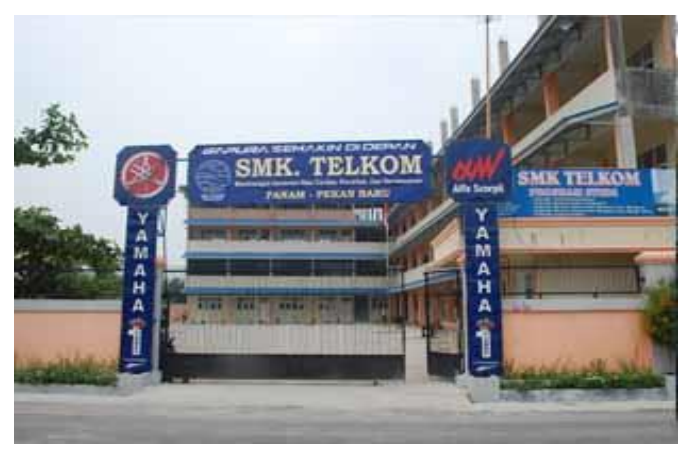

Gambar 1. Sekolah SMK Telkom

\section{Pekanbaru}

Kualitas tersebut apabila dimiliki oleh setiap lulusan SMK, tentu Indonesia tidak akan kekurangan generasi penerus bangsa yang potensial. Gambaran tersebut merupakan gambaran manusia unggul dan merupakan cerminan generasi penerus bangsa yang ideal.

\section{Gambar 2. Siswa dan Guru SMK} Telkom Pekanbaru

Sampah yang berasal dari aktivitas manusia yang dapat bersifat organik maupun anorganik. Contoh sampah organik adalah: sisa-sisa bahan makanan, kertas, kayu dan bambu. Sedangkan sampah anorganik hasil dari proses pabrik misalnya: plastik, logam, gelas, dan karet. Ditinjau dari kepentingan kelestarian lingkungan, sampah yang bersifat organik tidak begitu bermasalah karena dengan mudah dapat dirombak oleh mikrobia menjadi bahan yang mudah menyatu kembali dengan alam. Sebaliknya sampah anorganik sukar terombak dan menjadi bahan pencemar.

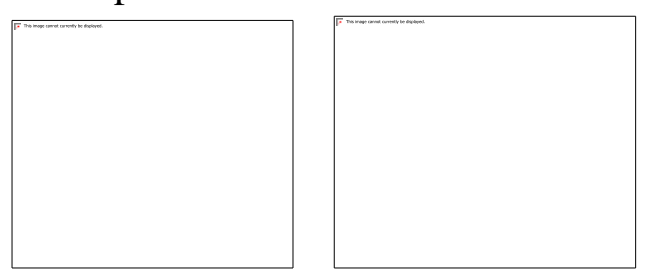

Gambar 3. Limbah Sampah Plastik Inovasi teknologi merupakan teknologi yang dirancang dan dikembangkan berdasarkan pada aspekaspek lingkungan, sosial, budaya, ekonomi, dan etika masyarakat pengguna. Hemat sumber daya, minim dampak polutif, mudah penggunaan dan perawatannya merupakan bagian yang menjadi perhatian.

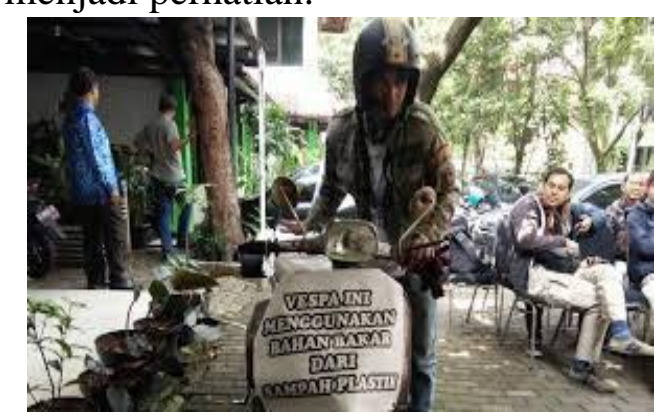

Gambar 4.Kendaraan berbahan bakar limbah sampah plastik

Masih kurangnya kesadaran siswasiswa dan guru SMK tentang manfaatmanfaat dari limbah sampah plastik yang bisa dikonversikan menjadi bahan bakar alternative. Hal ini mengindikasikan jika siswa dan guru SMK ini tidak diberikan pembinaan dan keterampilan maka sampah limbah plastik dapat menjadi pemicu munculnya masalah berdampak buruk bagi lingkungan karena sifat plastik yang memang susah diuraikan oleh tanah meskipun sudah tertimbun bertahun-tahun. 


\section{METODE PENGABDIAN}

Metode yang digunakan dalam penyuluhan pemanfaatan sampah limbah plastik sebagai bahan bakar alternatif yang ramah lingjkungan di SMK Telkom Pekanbaru adalah:

1. Metode Ceramah Dan Tanya Jawab

Teori yang disampaikan adalah pemanfaatan sampah limbah plastik sebagai bahan bakar alternatif yang ramah lingkungan.

2. Metode Demonstrasi

Metoda demonstrasi merupakan sistem penyajian sub kerja pelayanan penyuluhan pemanfaatan sampah limbah plastik sebagai bahan bakar alternatif yang ramah lingjkungan dengan teknis memperagakan kepada peserta. Metode demontrasi dan peragaan ini sangat efektif untuk penyuluhan pemanfaatan limbah sampah plastik.

Untuk mengetahui pencapaian tujuan kegiatan dilakukan evaluasi. Bentuk evaluasi yang dilakukan adalah mengamati cara kerja peserta mengikuti penyuluhan dan dinilai menurut kompetensi keterampilan. Evaluasi tersebut dilakukan dengan 2 cara yaitu; 1) Pengamatan secara langsung dari instruktur terhadap sikap para peserta, kehadiran peserta dan tanya jawab setiap akan masuk pada topik yang baru. 2) Hasil tes keterampilan reparasi dari hasil penyampaian penyuluhan dari masingmasing peserta.

Indikator keberhasilan dari kegiatan ini adalah; 1) Para peserta memiliki pengetahuan tentang teknik, 2) Para peserta memiliki keterampilan tentang teknik, 3) Membina kerjasama antar kelompok (team work)

\section{HASIL DAN PEMBAHASAN}

Sampah ini sebagian besar terdiri dari bungkus plastik dan botol minuman mineral. Untuk jenis terakhir inilah yang sekarang banyak dicari orang. Botol minuman bekas yang berbahan plastik
PET bisa didaur ulang menjadi biji plastik. Demikian juga halnya dengan kaleng minuman bekas yang berbahan logam. Sampah jenis ini juga sebaiknya dipilah, dikumpulkan untuk kemudian dijual. Anak-anak juga dapat berkreasi merangkainya menjadi barang kerajinan atau hiasan dinding.
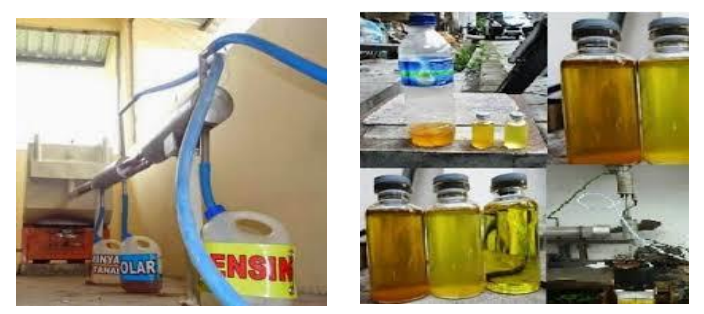

Gambar 5. Bahan bakar minyak dari limbah plastik

Dengan sistem pemilahan ini diharapkan siswa dapat belajar betapa sampah yang semula kotor dan menjijikkan ternyata memiliki nilai jual. Siswa akan menyadari bahwa peluang kerja ada di sekitarnya, bukan hanya dicari tapi dapat juga diciptakan.
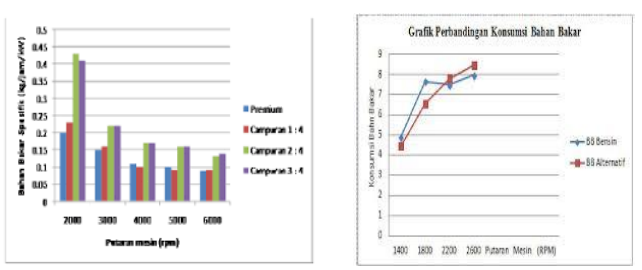

Gambar 5 Performa Sepeda Motor BBM Limbah Sampah Plastik

Hasil kegiatan pengabdian masyarakat secara garis besar mencakup beberapa komponen sebagai berikut; 1). Keberhasilan target jumlah peserta penyuluhan, 2). Ketercapaian tujuan kegiatan, 3). Ketercapaian target materi yang telah direncanakan, 4).Kemampuan peserta dalam penguasaan materi

Target peserta penyuluhan seperti direncanakan sebelumnya 20 orang yang jurusan TKR dan TSM. Dalam pelaksanaannya, kegiatan ini diikuti oleh 40 orang peserta. Dengan demikian dapat dikatakan bahwa target peserta tercapai 100\%. Angka tersebut menunjukkan bahwa kegiatan 
pengabdian masyarakat dilihat dari jumlah peserta yang mengikuti dapat dikatakan berhasil/ sukses. Ketercapaian tujuan pengabdian masyarakat secara umum baik, namun keterbatasan waktu yang disediakan mengakibatkan tidak semua materi tentang penggunaan bahan bakar gas dapat disampaikan secara detil. Namun dilihat dari hasil penyuluhan yaitu kualitas media yang telah dihasilkan, maka dapat disimpulkan bahwa tujuan kegiatan ini dapat tercapai.

Ketercapaian target materi pada kegiatan pengabdian ini cukup baik, karena materi penyuluhan telah dapat disampaikan secara keseluruhan. Materi penyuluhan yang telah disampaikan adalah; 1) Teori pengenalan alat dan penggunaannya, keselamatan kerja, 2) Teori Dasar-dasar dari sepeda motor, 3) Sosialisasi Kendaraan Berbahan Bakar limbah sampah plastik, 4) Praktek bahan bakar limbah plastik pada kendaraan bermotor

Kemampuan peserta dilihat dari penguasaan materi masih kurang dikarenakan waktu yang singkat dalam penyampaian materi dan kemampuan para peserta yang berbeda-beda. Hal ini disebabkan jumlah materi yang banyak hanya disampaikan dalam waktu sehari sehingga tidak cukup waktu bagi para peserta untuk memahami dan mempraktekkan secara lengkap semua materi yang diberikan. Secara keseluruhan kegiatan pengabdian masyarakat tentang penyuluhan pemanfaatan limbah sampah plastik sebagai bahan bakar alternatif ini dapat dikatakan berhasil. Keberhasilan ini selain diukur dari keempat komponen di atas, juga dapat dilihat dari kepuasan peserta setelah mengikuti kegiatan.

Manfaat yang diperoleh siswa dan guru smk yang jurusan teknik kendaraan ringan dan teknik sepeda motor dalam mengatasi krisis dari bahan bakar minyak dan dengan menggunakan bahan bakar plastik yang mempunyai kualitas yang lebih baik dan diharapkan kualitas tersebut dapat menggantikan bahan bakar minyak. Diharapkan setelah penyuluhan pemanfaatan limbah sampah plastik sebagai bahan bakar alternatif yang ramah lingkungan di SMK Telkom Pekanbaru dapat merencanakan Gerakan Ramah Lingkungan Menuju Kemakmuran dan Pemanfaatan Limbah Sampah Plastik Sebagai Bahan Bakar Minyak Alternatif di Tempat Pengolahan Sampah Akhir (TPSA) di SMK Telkom Pekanbaru.

\section{SIMPULAN}

Hasil yang dicapai melalui kegiatan Program Kemitra Masyarakat (PKM) ini tentang pemanfaatan limbah sampah plastik sebagai bahan bakar alternative pada sepeda motor yang ramah lingkungan adalah sebagai berikut :

1. Menambah ilmu pengetahuan dan keterampilan siswa SMK Telkom Pekanbaru tentang pemanfaatan limbah sampah plastik sebagai bahan bakar alternatif dengan pendekatan IPTEK terapan, mengalami peningkatan dari kategori kurang menjadi baik.

2. Rata-rata kemampuan SMK Telkom Pekanbaru menggunakan media pembelajaran inovasi teknologi yang telah dikembangkan sehingga berkualitas baik.

3. Terbukanya peluang-peluang bisnis untuk siswa SMK tentang pemanfaatan sampah plastik

4. Dapat membantu pemerintah dalam mengatasi penganguran.

\section{UCAPAN TERIMAKASIH}

Ucapan terima kasih atas pelaksanaan kegiatan pengabdian masyarakat kepada:

1. Rektor Universitas Muhammadiyah Riau yang telah menfasilitasi kegiatan pengabdian masyarakat ini. 
ISSN : 2550-0198

2. Ketua LPPM UMRI yang telah mengagendakan kegiatan pengabdian masyarakat di lingkunan dosen UMRI

3. Dekan Fakultas Teknik UMRI yang telah member dukungan atas pelaksaan pengabdian ini.

4. Ketua Program Studi Mesin Otomotif yang telah memotifasi kegiatan pengabdian ini.

5. Semua dosen dan mahasiswa Program Studi Mesin Otomotif yang terlibat dalam agenda pengabdian masyarakat ini.

\section{DAFTAR PUSTAKA}

[1]. Aprian, Ramadhan P., dan Ali Munawar. 2012. Pengolahan Sampah Plastik menjadi Minyak Menggunakan Proses Pirolisis. Envirotek: Jurnal Ilmiah Teknik Lingkungan, 4(1). Fakultas Teknik Sipil dan Perencanaan. UPN Jatim.

[2]. Ermawati, Rahyani. 2011. Konversi Limbah Plastik sebagai Sumber Energi Alternatif. Jurnal Riset Industri, Vol. V No. 3. Balai Besar Kimia dan Kemasan. Kementrian Perindustrian.

[3]. Herry, P., Setiawan, I. dan Gunawan, I. 2015. Pengaruh Kecepatan Pengadukan Dan Rasio Minyak/Metanol Pada Pemurnian Minyak Pirolisis Dari Limbah Plastik Polyethylene. Simposium Nasional Teknologi Terapan (SNTT). Universitas Muhammadiyah Surakarta.

[4]. Kabib, Masruki. 2009. Pengaruh Pemakaian Campuran Premium Dengan Champhor Terhadap Performasi Dan Emisi Gas Buang Mesin Bensin Toyota Kijang Seri 4K. Jurnal Sains dan Teknologi. 2/2 1-17. 